Jurnal Teknologi, 56 (Sains \& Kej.), Sept. 2011: 1-14

(C) Penerbit UTM Press, Universiti Teknologi Malaysia

\title{
CUTTINGS TRANSPORT IN HORIZONTAL AND HIGHLY DEVIATED WELLBORES
}

\author{
ALI PIROOZIAN ${ }^{1} \&$ ISSHAM ISMAIL ${ }^{2 *}$
}

\begin{abstract}
Deviation from vertical path makes drill cuttings to accumulate on the lower side of the wellbore that induces the formation of cuttings bed. Subsequently, relative problems occur while drilling. Excessive torque and drag, difficulties in running casing in hole and accomplishing good cementing jobs and mechanical pipe sticking are few of the classical examples of such problems. Therefore, a comprehensive understanding of influential parameters on hole cleaning seems to be essential. This paper presents results of an experimental study that was carried out to evaluate cuttings removal efficiency of three types of drilling fluid. Experiments were conducted using a 17 feet long opaque flow loop of 2 inch diameter as test section. For each test, the amount of cuttings transport performance (CTP) was determined from weight measurements. Three operating parameters were considered, namely drilling fluid viscosity, fluid velocity, and hole inclination. It showed that the use of high-viscosity drilling fluid improved CTP if the flow regime was turbulent. However, increasing viscosity when flow regime was transient or laminar flow lessened CTP gradually or sharply respectively. It was also revealed that an incremental increase in hole inclination from $60^{\circ}$ to $90^{\circ}$ has a positive effect on CTP. The most influential parameter in this study was fluid velocity in which a small raise of fluid velocity resulted in a substantial positive effect on hole cleaning.
\end{abstract}

Keywords: Cuttings removal efficiency; cuttings transport performance; drill cuttings; drilling fluid; hole cleaning

\begin{abstract}
Abstrak. Lencongan dari laluan tegak menyebabkan rincisan gerudi berkumpul pada bahagian bawah lubang telaga sehingga terbentuknya lapisan rincisan. Akibatnya, berlaku beberapa permasalahan operasi ketika berlangsungnya penggerudian. Daya seret dan kilas yang melampau, kesukaran yang dialami ketika penyorongan rentetan selongsong ke dalam lubang telaga, kesukaran untuk memperoleh operasi penyimenan yang baik, dan lekatan mekanikal paip gerudi adalah antara beberapa contoh lazim yang berkaitan dengan permasalahan terbabit. Sehubungan itu, pemahaman yang baik tentang parameter utama operasi yang mempengaruhi pembersihan lubang telaga adalah penting. Artikel ini mengetengahkan keputusan daripada kajian makmal yang telah dilaksanakan untuk menilai keberkesanan tiga jenis bendalir gerudi dalam menyingkir rincisan gerudi. Kajian makmal melibatkan penggunaan gelung legap aliran sepanjang 17 kaki dengan diameter 2 inci sebagai bahagian ujian. Bagi setiap uji kaji, prestasi pengangkutan rincisan
\end{abstract}

${ }_{1 \times 2}$ Department of Petroleum Engineering, Faculty of Petroleum and Renewable Energy Engineering, Universiti Teknologi Malaysia, 81310 UTM Johor Bahru

* Corresponding author: issham@petroleum.utm.mv 
(CTP - Cuttings Transport Performance) ditentukan menerusi pengukuran berat. Keputusan uji kaji dianalisis untuk memperoleh kesan menyeluruh ketiga-tiga parameter operasi, iaitu kelikatan bendalir gerudi, halaju bendalir, dan kecondongan lubang telaga. Kajian terkini membuktikan bahawa penggunaan bendalir gerudi berkelikatan tinggi berupaya meningkatkan CTP jika regim aliran adalah gelora. Walau bagaimanapun, peningkatan kelikatan dalam regim aliran peralihan atau laminar masing-masing mengurangkan CTP secara beransur atau mendadak. Kajian juga menunjukkan bahawa peningkatan sudut kecondongan dari $60^{\circ}$ ke $90^{\circ}$ memberikan kesan yang positif terhadap CTP. Parameter operasi yang memberikan kesan yang ketara dalam kajian ini ialah halaju aliran, dengan peningkatan kecil yang dialami oleh halaju aliran berjaya memberikan kesan positif yang nyata dalam pembersihan lubang telaga.

Kata kunci: Kecekapan penyingkiran rincisan; prestasi pengangkutan rincisan; rincisan gerudi; bendalir gerudi; pembersihan lubang telaga

\subsection{INTRODUCTION}

The significance of drilling horizontal and highly deviated wells particularly in the near future has attracted many oil companies' interest. Economically speaking, it is not always sensible to use conventional vertical drilling in the case of offshore fields, and sometimes it is even out of reach. Thus, the best alternative is exploiting deviated wells to bypass most obstructions. However, this approach is not devoid of deficiency while drilling. Excessive torque/drag, upright equivalent circulation densities, lost circulation, barite sag, inefficient hole cleaning and frequent sticking are some of the problems encountered while drilling horizontally (Cameron, 2001).

Generally, the slightest nuance in the angle of deviation will lead to changing of the lifting power of the mud. As the direction of drilling is shifted from vertical to horizontal orientation, capacity of drilling fluid for carrying drill cuttings will reduce. This happens due to the tendency of cuttings to lie down along the low sidewall of the annulus rather than being lifted out (Fadario, 2009). Therefore, many engineering problems such as hindering drillpipe sliding and limiting the lateral reach of the well may occur. These obstacles directly and indirectly contribute to many other problems. The capacity of drilling fluid to carry the drill cuttings determines the quality performance of hole cleaning (Sifferman and Becker, 1992). As long as hole cleaning operation is done adequately, mechanical drillpipe sticking, high torque and drag, bottom hole and bit balling, lost of circulation, deploying logging equipment, difficulties in running casing string and formation damage can be avoided. Consequently, lower drilling time is required which reduces drilling expenditure significantly. It is beyond doubt that insufficient hole cleaning can reverse the operation outcome. Hence, a good understanding of hole cleaning is essential to prevent the unnecessary operational problems. 
Moist oilfield owners always work with drilling companies that can offer lower rig time. That is why penetration rate and the applied method go first. Besides, certain government restrictions should be taken into consideration before making any decision. Thus, all influential factors should be well examined beforehand. Strictly speaking, it is hard to turn a blind eye on the priority of cutting transportation in oil drilling operations especially after coupling with the potential well problems as highlighted earlier, which has lead this study to focus on the issue.

\subsection{EXPERIMENTAL WORK}

This study was carried out in the Heavy Duty Laboratory of Faculty of Petroleum and Renewable Energy Engineering, Universiti Teknologi Malaysia, to have a sufficient vacant space to construct the designed rig of this research. Preparation of each segment was briefly discussed in the following section.

\subsection{Flow Loop Design and Experimental Set-up}

With the aim to achieve the purpose of this study which was to examine the effect of three influential parameters on cuttings transport, namely fluid viscosity, hole inclination and fluid velocity, an experimental rig was built. The rig has the potential to carry out all specified experiments in a low-pressure and lowtemperature (ambient temperature) system (Figure 1). Field conditions had been considered in determining the size and the shape of the annulus flow section. For this study, the section selected is planned to be drilled with $216 \mathrm{~mm}$ bit $(\approx 8.5 \mathrm{in})$ while utilizing large-diameter drillpipe of $168 \mathrm{~mm}$ (6 5/8 in). The test section was 17 feet long ( $\approx 5$ meters), consisting of an opaque PVC outer casing (2 in ID and $2 \frac{1}{2}$ in OD) and a hollow steel inner drill pipe (1 1/2 in OD). A 1 H.P. centrifugal pump was used to circulate fluid into the flow loop. The cuttings were injected at the inlet of the annular test section where they merged with the test section.

Coarse sands taken from nearest coast were selected as solid particles. They were sieved, washed, dried, and weighed respectively. All particles had an irregular shape with an average size of $1.70 \mathrm{~mm}$. After drying all sands, they were separated using a plastic bag into groups of $163 \mathrm{~g}$ each (adding $2 \mathrm{~g}$ more for the weight of each plastic bag, therefore, the weight of each sample including the weight of plastic bag was $165 \mathrm{~g}$ ). 


\subsection{Drilling Mud}

Water-based drilling muds were prepared containing various amounts of bentonite and CMC (Carboxymethyl Cellulose) for this project. Stock suspension of bentonite was prepared by adding bentonite to tap water and shearing at a high rate for six hours. Stock solutions of the polymers were prepared by dissolving the polymers in tap water at a low shear rate and stirring continuously until clear solutions were obtained. The mud finally was mixed at a moderate shear rate with a mixer.

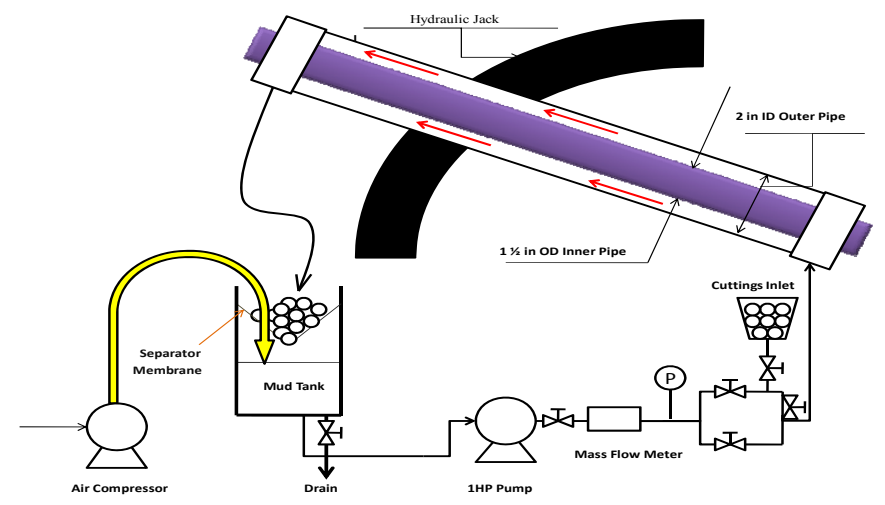

Figure 1 Schematic diagram of the flow loop

\subsection{Experimental Procedure}

The first step to start the experiment was to prepare the cuttings. After cuttings were sieved and washed, it was time to dry them, weight them to $162 \mathrm{~g}(0.324 \mathrm{lb})$ and then placed them in a plastic bag. The total amount of sieved cuttings which were prepared prior to each run exceeded $30 \mathrm{~kg}(66.2 \mathrm{lb})$. Each run consisted of four experiments and was dedicated for only one angle. All of these experiments were run without rotating the inner pipe for four flow rates $(37.9,45.4,53.0$, and $68.1 \mathrm{~L} / \mathrm{min})$. For the subsequent experiment, the same previous pattern was followed except using a new angle. This trend was repeated till all four experiments were fully implemented (Figure 2). After completion of all experiments and termination of first run, the second run was carried out with a new mud with a new viscosity (higher viscosity). To do so, CMC was used as another viscosifier besides bentonite. 
Percentage of recovery can be calculated using the following equation:

$$
\text { Recovery }(\%)=\frac{\text { Final dried weight } \times 100}{\text { Initial dried weight }}
$$

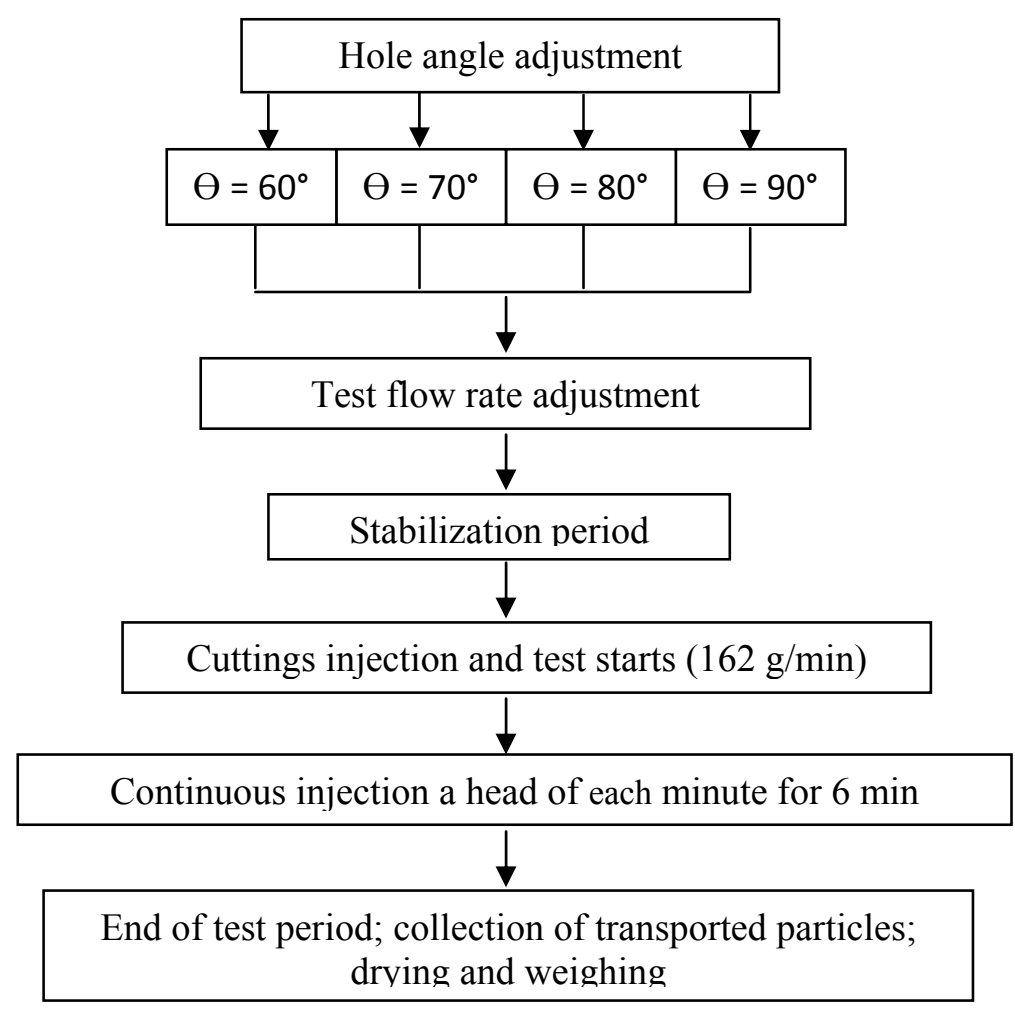

Figure 2 Experimental procedure chart

\subsection{RESULTS AND DISCUSSION}

\subsection{Effect of Fluid Viscosity}

According to this study, increasing the plastic viscosity of the mud results in a remarkable increase in the amount of recovered drill cuttings. Surprisingly, the surplus amount of viscosity inverses the result. These phenomena are clearly seen in Figures 3(a) - (d).

As far as cuttings transport in highly deviated wells is concerned, researchers offer various ideas about the effect of viscosity on hole cleaning. Some researchers 
such as Zeidler (1972), Okrajni (1986), Doron (1996), Pilehvari (1999), Kamp (2000), and Gravignet (2003) believe that raising viscosity of the drilling fluid deteriorates hole cleaning, because type of flow regime changes from turbulent flow to laminar flow; and it has been proved that cuttings can be better displaced in turbulent flow than laminar flow. On the other hand, there are also some investigators, for instance, Ford (1990), Zhou (2000), Martings (2001), Doan (2003), Bilgesu (2007) who claim that improvement in hole cleaning occurs as viscosity increases.

Figures 3(a) - (d) are for $1.74 \mathrm{~mm}$ cuttings size and each figure is a representative of one specific angle (i.e., $60^{\circ}, 70^{\circ}, 80^{\circ}$, or $90^{\circ}$ ). In all figures, cuttings transport performance (CTP) has been plotted versus viscosity. A line in each individual graph depicts a constant flow rate for the three distinctive types of drilling fluid with three different viscosities $(1,2.5$, and $6 \mathrm{cp})$.

It is visible from Figures 3(a) - (d) that primary increasing viscosity from $1 \mathrm{cp}$ to $2.5 \mathrm{cp}$ results in better CTP for all four different flow rates regardless of hole inclination. The effect of viscosity was, nevertheless, negative when the viscosity of the mud was intensified to $6 \mathrm{cp}$. The best explanation for such a behavior of mud can be extracted from rheological laws defined for distinguishing various types of flow, namely laminar flow, transient flow, and turbulent flow. The type of flow of a fluid is characterized by the Reynolds number (Re).

It is true to say that by increasing viscosity of the fluid at the same flow rate, the current flow regime tends to convert to laminar flow from turbulent flow. However, it should be noticed that converting a turbulent flow to laminar flow requires passing through a wide range of Reynolds number including transition zone. Thus, the author prepared a general graph, which indicates how viscosity affects cuttings transport performance by changing flow regime, as a hypothesis (Figure 4).

It can be interpreted from Figure 4, that CTP is improved by increasing viscosity while other factors such as velocity and hole inclination are kept constant. This happens until the flow is still turbulent, but once reaching the transition zone CTP gradually decreases till the end of this region. Subsequently, laminar flow becomes transition flow by further increasing of viscosity at the same condition. Among those three types of flow regimes, turbulent flow is the most desirable one followed by transition and laminar flows. The effect is prevailing at lower and higher velocities and for all hole inclinations. All these phenomena can be explained by the definition of each flow regime. As the flow is laminar, any laminar layer of the fluid is displaced, with respect to other laminar layers, in parallel to the direction of flow, and is moving at its individual speed. For flow through a cylindrical tube, the flow rate is highest along the axis of the tube. At the tube wall it is zero in the throughout the volume of the fluid. However, turbulent flow consists of small eddies throughout the volume of the fluid, and this character 
of this type of flow produces more momentum force which gives better movement of cuttings of course.

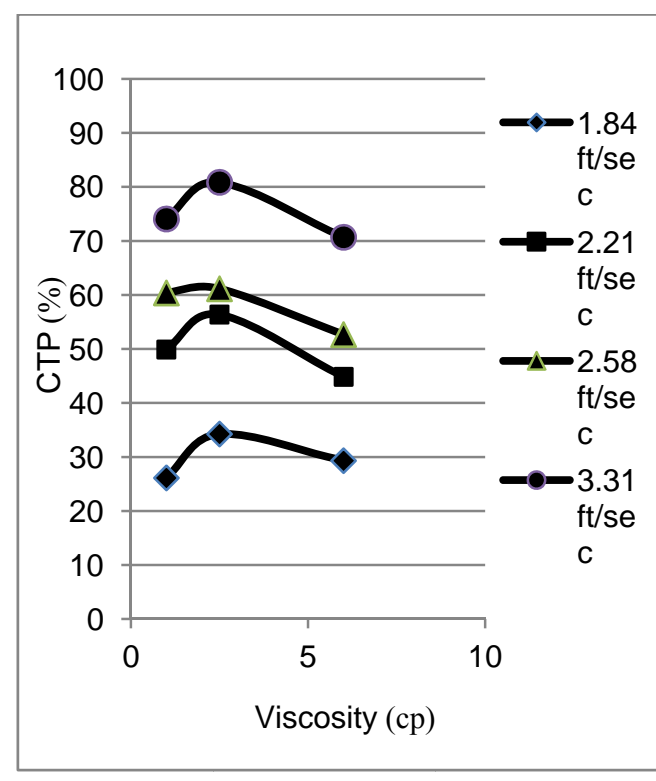

(a)

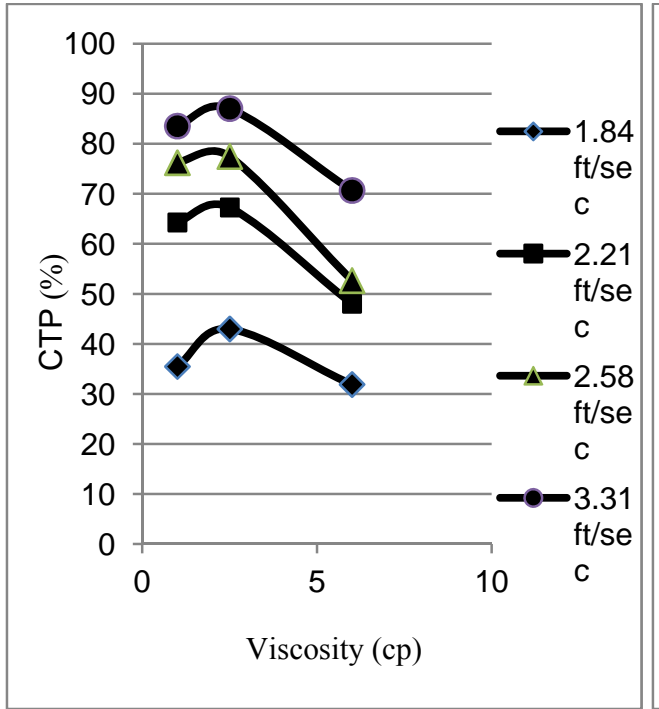

(c)

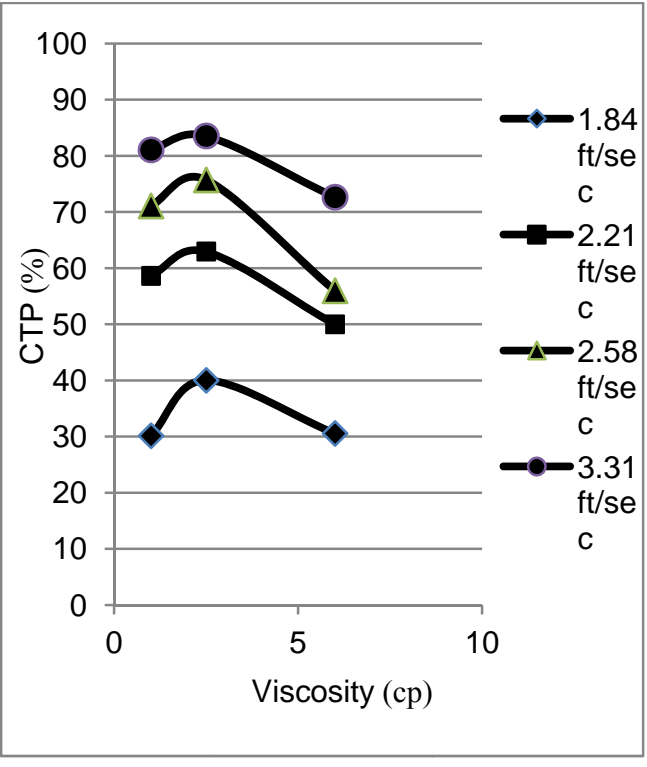

(b)

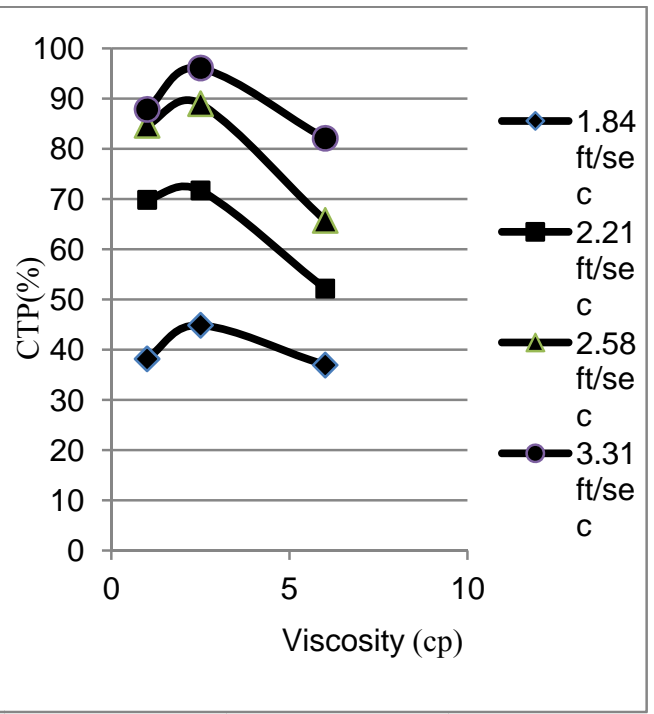

(d)

Figure 3 Cuttings transport performance versus viscosity for four distinct hole inclinations from vertical: (a) $\Theta=60^{\circ}$, (b) $70^{\circ}$, (c) $80^{\circ}$, and (d) $90^{\circ}$, with different flow velocities 


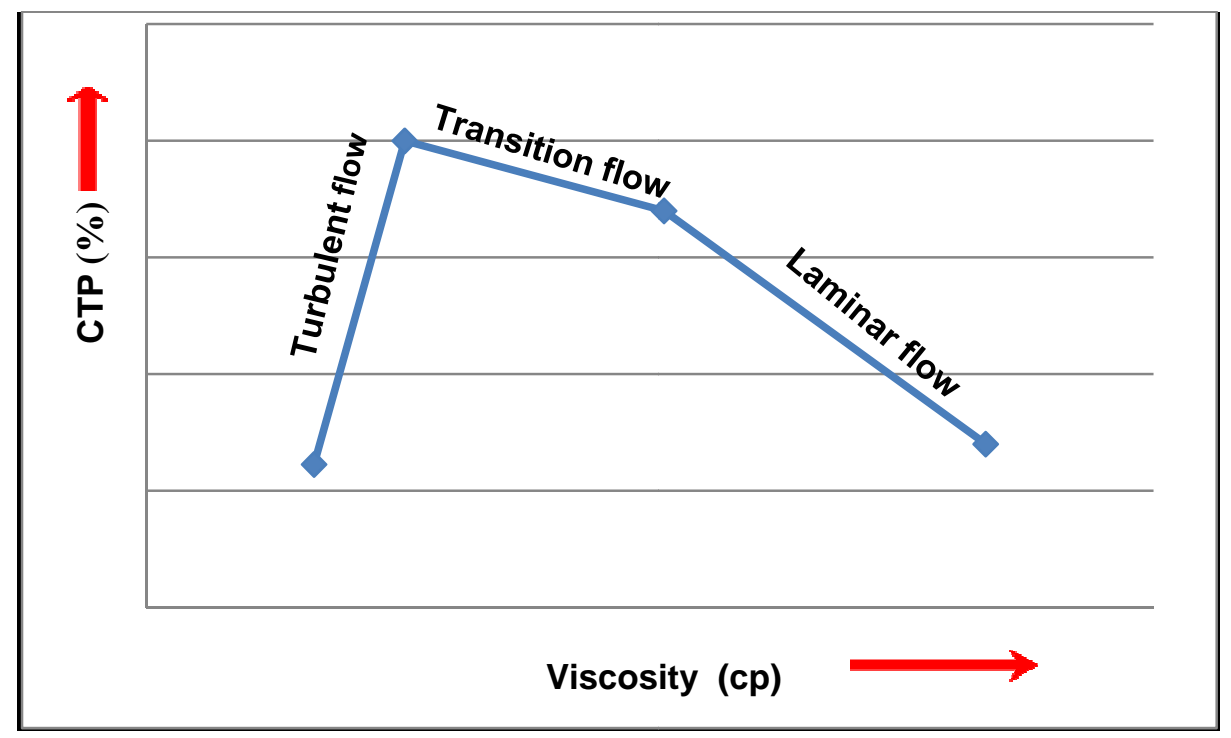

Figure 4 Effect of viscosity by changing the flow regime

\subsection{Effect of Hole Inclination}

In the laboratory work, it was observed that the angle of the well played an important role in transporting drill cuttings. This is the reason why hole cleaning is more challenging in directional wells as compared to vertical wells. Figures 5(a) (d) clearly illustrate the effect of hole inclination on hole cleaning. In each curve, hole inclinations have been plotted versus CTP for one value of velocity and different liquid viscosities. For high angles, where an immobile cuttings bed can form, transport is via rolling mechanism. In intermediate angles, where a churning, moving cuttings bed can form, transport is via a lifting mechanism. At near-vertical angles, particle settling determines transport efficiency.

Curves in these figures indicate types of chosen mud in every run of the experiment. Rhombic markers belong to the mud with viscosity of $1 \mathrm{cp}$, square markers have a viscosity of $2.5 \mathrm{cp}$ and triangle markers have the highest viscosity by the value of $6 \mathrm{cp}$. The existing distance between curves also shows different types of mud with different rheological properties. Four angles had been selected for this study namely $60^{\circ}, 70^{\circ}, 80^{\circ}$, and $90^{\circ}$ from vertical. All curves give an upward trend by diverging test section from vertical, indicating that CTP has improved. Some researchers, such as Okrajni (1986), Tomren (1992), and Bilgesu 
(2007), believed that if hole angle increases, their negative influences on cutting transports will increase as well. However, they believe that it also has some positive effects especially when the flow is laminar. It is obvious that at higher degrees of inclination the tendency of downward cuttings bed sliding is more likely to occur which increases the hydraulic requirement for adequate hole cleaning. These beds moved at a lower speed along the annular space so that at the end of the test period, there may be some beds about to approach the outlet of the annulus section and if the test period has lasted for a few extra minutes, there is a great chance for the nearby moving beds to leave the annular section. Thus, it is believed that a slight increase in hole inclination causes these large moving bed to reach the outlet before the end of the test period; thus a considerable increase in weight of recovered particles (WRP) and CTP.

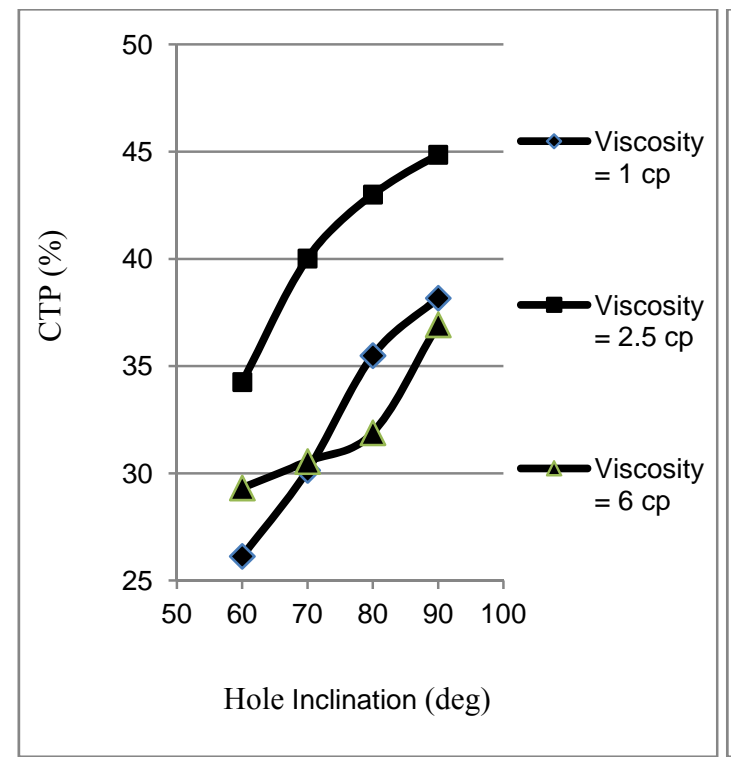

(a)

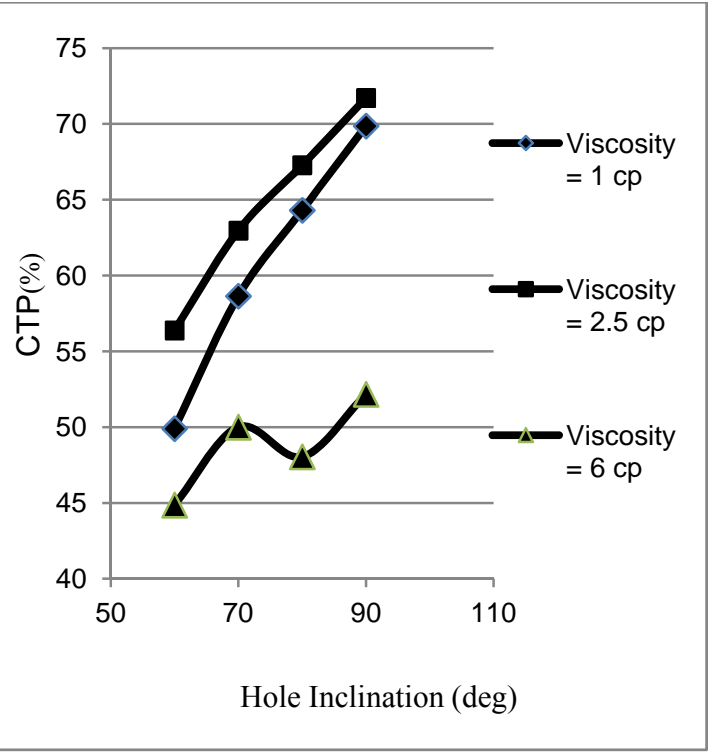

(b) 


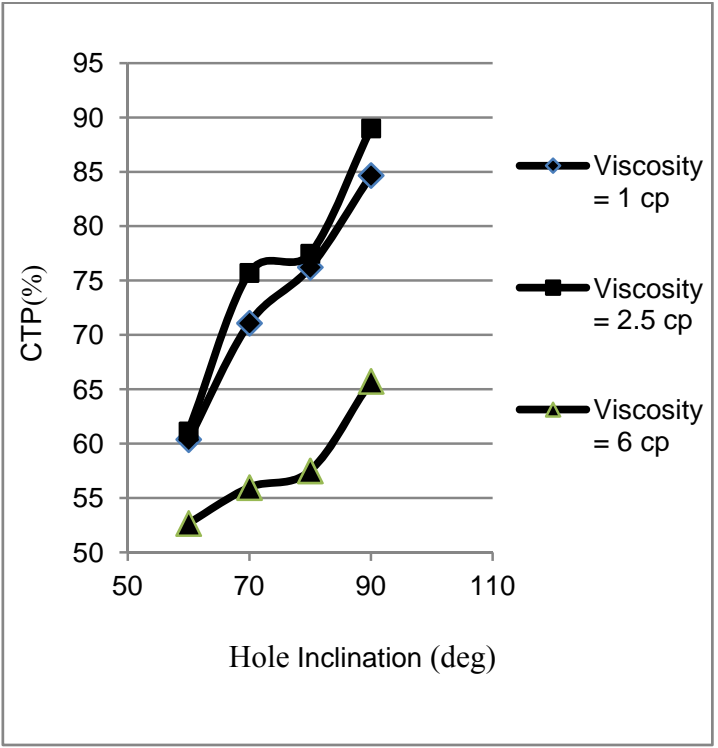

(c)

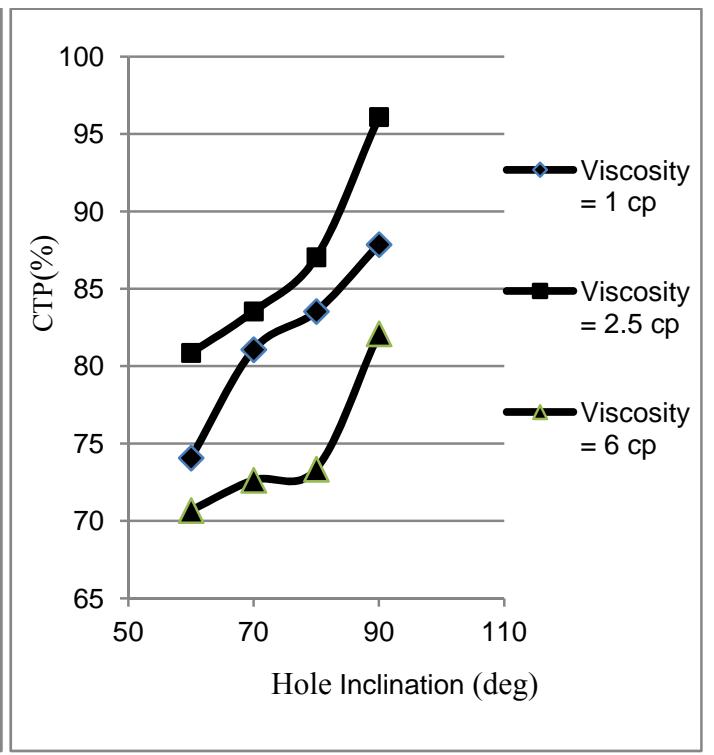

(d)

Figure 5 Cuttings transport performance versus hole inclinations for four miscellaneous fluid velocities: (a) $\mathrm{V}=1.84(\mathrm{ft} / \mathrm{sec})$, (b) $2.21(\mathrm{ft} / \mathrm{sec})$, (c) $2.58(\mathrm{ft} / \mathrm{sec})$, and (d) $3.31(\mathrm{ft} / \mathrm{sec})$, with different fluid viscosities

\subsection{Effect of Annular Fluid Velocity}

When the influence of velocity on hole cleaning was analyzed, it has been observed that the velocity has a positive contribution of removal of stationary bed. This is an interpretation taken form Figures 6(a) - (d). As it can be seen in all figures, the incremental increase in annular velocity brings a substantial increase in cuttings transport. The effect is more significant in higher hole inclinations and higher fluid viscosities.

The most portions of injected cuttings were recovered by highest velocity of the drilling fluid and the most viscous mud. This fact also supports previous discussion about viscosity of mud in which increasing the viscosity can improve CTP if the flow regimes is still turbulent. These results coincide well with vast majority of previous experimental work. Many researchers have already reported the effect of flow rate on hole cleaning, such that as the flow rate is increased, a reduction on cuttings bed area will be experienced. 


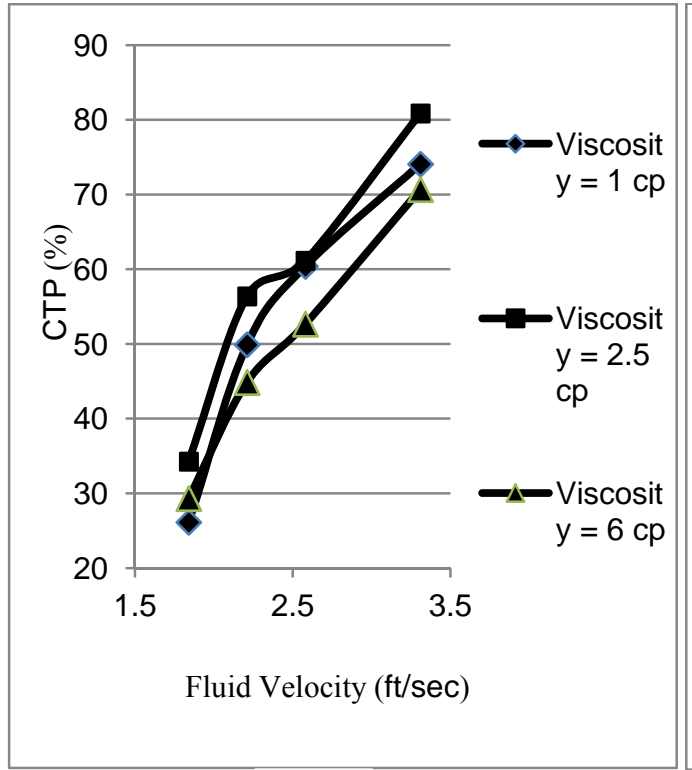

(a)

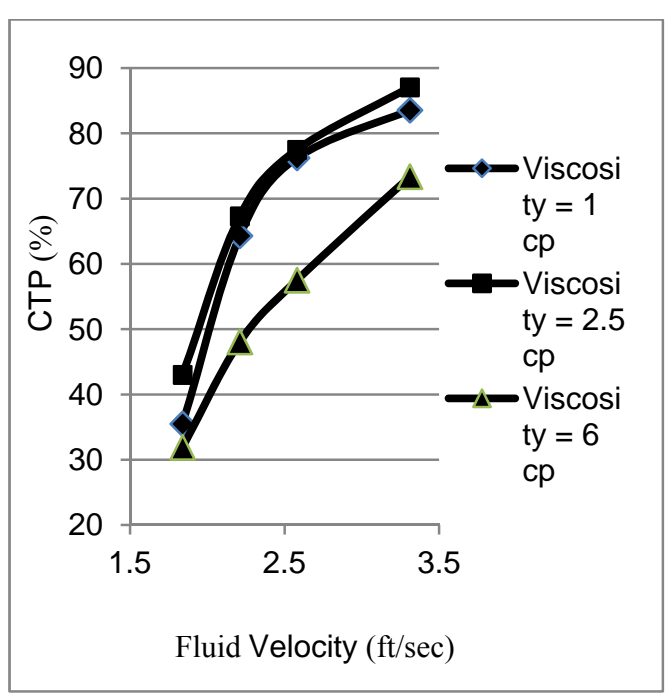

(c)

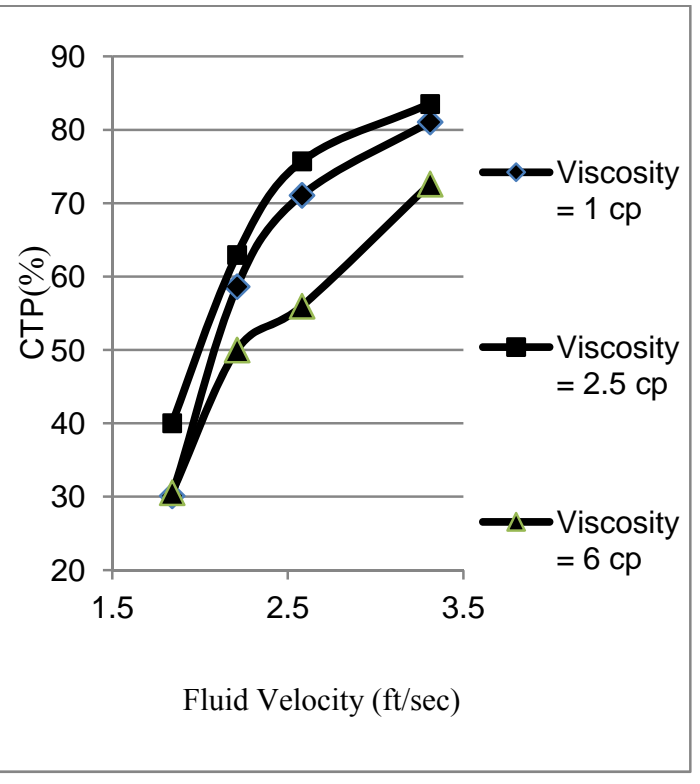

(b)

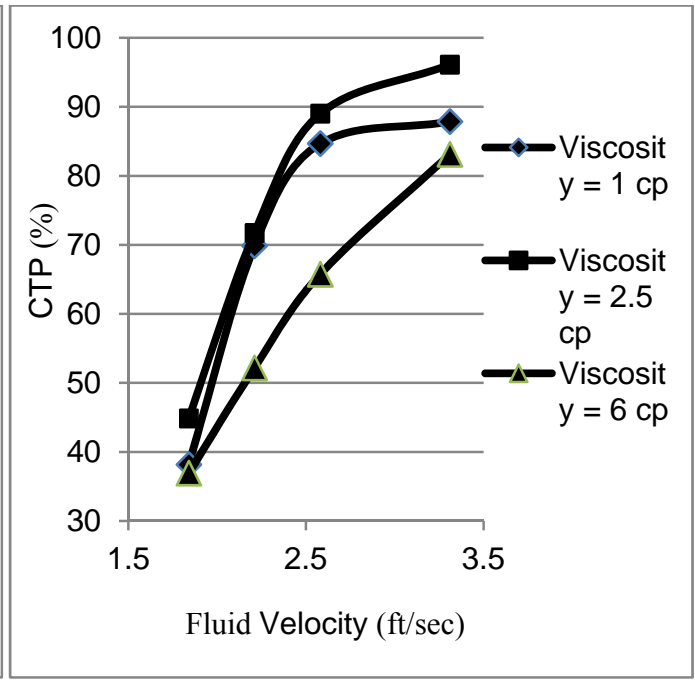

(d)

Figure 6 Cuttings transport performance versus fluid velocity for four distinct hole inclinations from vertical: (a) $\Theta=60^{\circ}$, (b) $70^{\circ}$, (c) $80^{\circ}$, and (d) $90^{\circ}$, with different fluid viscosities 


\subsection{CONGLUSIONS}

This research study was aimed to concentrate more on the effect of viscosity on CTP, since there are some contradictions among previous studies about this issue. To do so, a simulated borehole was designed and constructed. From all the influential parameters only three of them, i.e. hole inclination, fluid viscosity and velocity, were selected regarded as the objectives of this study. The important points concluded from this study are as follows:

(1) According to this study, increasing the plastic viscosity of the mud results in a remarkable raise in the amount of recovered cuttings. Surprisingly enough, the surplus amount of viscosity inverses the result. This phenomenon is explained well by using a proposed graph which has been prepared by the author. From the graph it can be observed that cuttings transport performance (CTP) is improved by increasing viscosity while other factors such as flow regime which depends on velocity and hole inclination are kept constant. This happens until the flow is still turbulent, but reaching the transition zone CTP gradually decreases till the end of this region. Subsequently, laminar flow is substituted for transition flow by further increasing of viscosity at the same condition. Among those three types of flow regimes, turbulent flow is the most desirable one followed by transition and laminar flows. The effect is prevailing at lower and higher velocities and for all hole inclinations.

(2) During all experiments in this investigation, it was observed that the angle of the annulus played an important role in transporting of drilled cuttings. This is the reason why hole cleaning is more challenging in directional wells rather than the vertical wells. Some researchers believe that if hole angle increases, their negative influences on cutting transports will increase as well. However, the operator of this study believes that it also has some positive effects especially when the flow is laminar. It is obvious that at higher degrees of inclination, the tendency of downward cuttings bed sliding is more likely to occur which increases the hydraulic requirement for adequate hole cleaning. These beds moved at a lower speed along the annular space so that at the end of the test period, there may be some beds 
about to approach the outlet of the annulus section and if the test period has lasted for a few extra minutes there is a great chance for the nearby moving beds to leave the annular section. Thus, it is believed that a slight increase in hole inclination causes these large moving beds to reach the outlet before the end of the test period; thus a considerable increase in WRP and CTP.

(3) When the influence of velocity on hole cleaning was analyzed, it has been observed that the velocity has a positive contribution of removal of stationary bed. The incremental increase in annular velocity brings a substantial increase in cuttings transport. The effect is more significant in higher hole inclinations and higher fluid viscosities. The most portions of injected cuttings were recovered by highest velocity of the drilling fluid and the most viscous mud. This fact also supports previous discussion about viscosity of mud in which increasing the viscosity can improve CTP if the flow regimes is still turbulent.

\section{REFERENCES}

[1] Bilgesu, M. N. and G. A. Chukwu. 2007. Experimental Study of the Parameters Affecting Cuttings Transport in a Vertical Wellbore Annulus. SPE paper 27880 presented at the Western Regional Meeting held in Long Beach, California. Mac. 23-25.

[2] Cameron, C. 2001. Drilling Fluids Design and Management for Extended Reach Drilling. IADC/SPE 72290 paper presented at the IADC/SPE Middle East Drilling Technology Conference, Bahrain. Oct. 22-24.

[3] Cho, S. and G. H. Medly. 2000. A Three-Segment Hydraulic Model for Cuttings Transport in Horizontal and Deviated Wells. SPEDE J. Feb. 43 - 56.

[4] Doan, R. and E. Condolios. 2003. Experimental Study of the Hydraulic Transport of Coal and Solid Material in Pipes. Proceedings of Colloquium on the Hydraulic Transport of Coal held by National Coal Board, London, U. K. Nov 5-6. Paper IV. 39-55.

[5] Doron, P. and D. Barena. 1996. Flow Pattern Maps for Solid-Liquid Flow in Pipes. Int. J. MPF. 22(2): 273-283.

[6] Ford, J. T., J.M. Peden, and M. B. Oyeneyin. 1990. Experimental Investigation of Drilled Cuttings Transport in Inclined Boreholes. SPE paper 20421 presented at the $65^{\text {th }}$ Annual Technical Conference and Exhibition held in New Orleans, LA. Sep. 23-26.

[7] Fadairo, A., and S. Adesina. 2009. Effect of Drilling Cuttings Transport on Pressure Drop in a Flowing Well. SPED J. Oct. 26-28.

[8] Gravignet, T. and T.I. Sobey. 2003. Drilling and Well Completions. Englewood Cliffs, N. J.: Prentice-Hall.

[9] Kamp, M. and K. Rivero. 2000. Carring Capacity of Drilling Mud. Transaction. AIME. 191. 111120. 
[10] Martings, U. and F. Santana. 2001. Modeling and Simulation of Annular Axial Flow of Solids and Non-Newtonian. Mixtures, papers presented at the Encontro Nacional de Ciencias Termicas, Itapema, Brazil.

[11] Mohamed, N. N. and A. Mohamed. 2010). Effect of Borehole Inclination, Annular Clearance, on the Hole Cleaning Efficiency for Water Based Driling Muds. SPEDC J. Apr 04-07.

[12] Okrajni, S. S. and J. J. Azar. 1986. The Effect of Mud Rheology on Annular Hole Cleaning in Directional wells. SPED J. Aug. 297-308.

[13] Pilehvari, A. A., J. J. Azar, and S. A. Shirazi. 1999. State-of-the-Art Cuttings Transport In Horizontal Wellbores. SPEDC J. Sep. 196-200.

[14] Sifferman, T. R. and Becker, T. E. 1992. Hole Cleaning in Full-scale Inclined Wellbores. SPEDE J . Jun. 115-120.

[15] Tomren, P. H., A.W. Iyoho, and J. J. Azar. 1986. Experimental study of cuttings transport in directional Wells. SPEDE J. Feb. $43-56$.

[16] Zeidler, H. U. 1972. An Experimental Analysis of the transport of drilled Particles. SPE J. Feb. 3948.

[17] Zhou, I. 2000. Advances in Solid liquid Flow in Pipes and Its Application. Headington Hill Hall, Oxford: Pergamon Press Limited. 